Travels in the

Genetically

Modified Zone

हो: 



\section{Travels in the}

Genetically

Modified Zone

\section{MARK L. WINSTON}

Harvard University Press

Cambridge, Massachusetts

London, England 
Copyright (C) 2002 by the President and Fellows of Harvard College All rights observed

Printed in the United States of America

First Harvard University Press paperback edition, 2005

Library of Congress Cataloging-in-Publication Data

Winston, Mark L.

Travels in the genetically modified zone / Mark L. Winston.

p. $\mathrm{cm}$.

Includes bibliographical references and index.

ISBN 0-674-00867-7 (hbk. : alk. paper)

ISBN 0-674-01529-0 (pbk. : alk. paper)

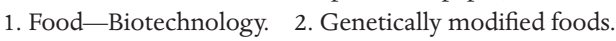

3. Agricultural biotechnology. I. Title.

TP248.65.F66 W565 2002

$664-\mathrm{dc} 21$

2002017192 
To Sue, for sharing her genome and the importance of nature and nurture

And for Devora, who daily reminds us of the profound wonder of creation and recombination

Ex: 
